Review

\title{
Available Resources for Algal Biofuel Development in China
}

\author{
Shuhao Huo ${ }^{1,2}$, Renjie Dong ${ }^{1}$, Zhongming Wang ${ }^{2, *}$, Changle Pang ${ }^{1}{ }^{*}$, Zhenhong Yuan ${ }^{2}$, \\ Shunni Zhu ${ }^{2}$ and Li Chen ${ }^{1}$
}

1 College of Engineering, China Agricultural University, Beijing 100083, China;

E-Mails: huoshuhao@yeah.net (S.H.); rjdong@cau.edu.cn (R.D.); chenli329@yahoo.cn (L.C.)

2 Guangzhou Institute of Energy Conversion, Chinese Academy of Sciences, Guangzhou 510640, China; E-Mails: yuanzh@ms.giec.ac.cn (Z.Y.); zhusn@ms.giec.ac.cn (S.Z.)

* Authors to whom correspondence should be addressed; E-Mails: wangzm@ms.giec.ac.cn (Z.W.); pangcl@cau.edu.cn (C.P.); Tel.: +86-20-87057760 (Z.W.); +86-10-62737885 (C.P.); Fax: +86-20-87057737 (Z.W.); +86-10-62737885 (C.P.).

Received: 27 June 2011; in revised form: 17 August 2011 / Accepted: 23 August 2011 / Published: 31 August 2011

\begin{abstract}
Microalgal biofuel research in China has made noticeable progress, and algae cultivation for biofuel production is considered to be an important contribution to Greenhouse Gas (GHG) mitigation and energy security. In this paper, the algal biofuel potentiality in China was reviewed from the points of view of algal biodiversity, algal culture collection, GHGs (especially $\mathrm{CO}_{2}$ ) mitigation, and the availability of the required sunlight, wastewater and land resources. The cultivation of microalgae utilizing power plants gas with large amounts of $\mathrm{CO}_{2}$ and wastewaters from urban households, industry and animal husbandry are suitable for large scale production in China. Land is hardly a limitation for algae cultivation.
\end{abstract}

Keywords: algae; biofuel; biodiversity; resources; China

\section{Introduction}

Due to the concerns about energy security and climate change, biofuel development and utilization have received high attention in China. However, biofuel production from cereals, sugar crops, or animal fats, which is much easier and almost cost competitive with other biomass feedstocks, is not encouraged 
in China because it competes directly with food supplies. Lignocellulosic ethanol technology is still under development. The yield of biodiesel production is quite low compared with the need [1].

The promise of clean and sustainable energy production from algae has generated tremendous interest recently. Algae are the fastest-growing plants and the most widely distributed organisms in Nature. The dry cell weight contains about 50\% oil [2]. Algae are a large group of photoautotrophic, mixotrophic and heterotrophic lower plants. Algae can be typically subdivided into two major categories, based on their relative sizes: macroalgae and microalgae. Microalgae are capable of producing 30 times the amount of oil per unit area of land, compared to oilseed crops [3]. It is the first largest biomass resource. Microalgae are abundant in diverse ecological aquatic habitats such as fresh, brackish, marine, and hypersaline water environments within a wide range of temperatures, $\mathrm{pH}$ values and salinity. Theoretically, microalgae could grow in different kind of water, nutrients, and land saving sites for oil production. Even better production can be achieved in the desert, where the sunlight is stronger [4].

There are a large number of potential pathways for the conversion of microalgal biomass into lipids, ethanol, hydrogen, methane, hydrocarbon and carbohydrates. The lipids can be refined into biodiesel for land transportation and even for aviation use. Microalgal biodiesel has become one of the potential third-generation biofuels. $\mathrm{CO}_{2}$, sunlight, water, and land are the main natural resources required for algal production. For large-scale cultivation of microalgae, the major problem is how to reduce the cost of media. China has a lot of waste resources that can be utilized for biomass production. The recycling of waste resources is a win-win way for simultaneous industrial microalgae cultivation and waste treatment.

\section{Algal Biodiversity in China}

With a large sea area, abundant freshwater resources, complex topography and diverse climates, China is one of the countries with the greatest diversity of algal resources [5]. Algae are distributed widely in oceans, various inland waters and wetland surfaces. Among them, those which live in the sea, oceans and inland saltwaters are saltwater algae, those which live in inland freshwater bodies are freshwater algae (Table 1).

Table 1. Comparison of the species number of algae between china and the world $[5,6]$.

\begin{tabular}{|l|c|c|c|c|c|c|}
\hline \multirow{2}{*}{ Category } & \multicolumn{2}{|c|}{ In the World } & \multicolumn{2}{|c|}{ In China } & \multirow{2}{*}{ Freshwater (\%) } & \multirow{2}{*}{ Seawater (\%) } \\
\cline { 2 - 5 } & Freshwater & Seawater & Freshwater & Seawater & & 5 \\
Cyanobateria & 1600 & 2000 & 1000 & 99 & 63 & 0 \\
Euglenophyta & 800 & 0 & 600 & 0 & 75 & 18 \\
Diatomeae & 8000 & 8336 & 4000 & 1485 & 50 & 35 \\
Chrysophyta & 701 & 49 & 100 & 17 & 14 & 25 \\
Xanthophyta & 381 & 20 & 25 & 5 & 7 & 32 \\
Cryptophyta & 60 & 19 & 15 & 6 & 25 & 7 \\
Prymnesiophyta & 0 & 500 & 0 & 34 & 0 & 17 \\
Phaeophyta & 8 & 1500 & 3 & 260 & 38 & 8 \\
Dinozoa & 50 & 4000 & 30 & 302 & 60 & 14 \\
Rhodophyta & 0 & 4100 & 0 & 569 & 0 & 27 \\
Chlorophyta & 8000 & 600 & 3000 & 163 & 38 & 14 \\
\hline Total & 19,600 & 21,124 & 8773 & 2940 & 45 & \\
\hline
\end{tabular}




\subsection{Algal Biodiversity in China Seas}

In 2007, the 2940 species of algae recorded from Chinese seas belong to 10 phyla (calculated to represent about $14 \%$ of the total World species). In contrast, the number of species of algae recorded was 2589 in 1994. In recent decades, with the deepening of the research work, more species have been found, but species of some phyla like Cyanobateria and Chlorophyta are decreasing because of deteriorating water quality. Among them, the species of Diatomeae is the most dominant phylum and it takes up $40 \%$ of the World's marine primary productivity [7]. In 2007, the species of Diatomeae in China seas was 1485 or $50.5 \%$ of the total number of species.

Approximately 120 species of phytoplankton, dominated by eurythermal, low salinity, diatom species, have been recorded in the Bohai Sea. The dominant species are Coscinodiscus, Chaetoceros, Rhizosolenia, and Skeletonema costatum. While some green algae are dominant in the inter-tidal zones, brown and red algae dominant in sub-tidal zones have been recorded. In the Yellow Sea, about 386 species of phytoplankton, dominated by Coscinodiscus, Chaetoceros, Rhizosolenia, Biddulphia, Nitzschia and Peridinium, have been recorded, with various ecologies indicative of temperate seas $[5,6]$. In the East China Sea, 64 species of phytoplankton occur in the areas near the estuary of the Yangtze River and 261 species appear in off-shore areas in Zhejiang. The dominant algae are Coscinodiscus, Skeletonema costatum, Chaetoceros lorenzianus and Nitzschia pungens. Neritic species are the most common ecological type. In the South China Sea, the number of phytoplankton species is different between regions and ranges from 104 to 260. They belong to two large groups, diatoms and dinoflagellates, among which Chaetoceros and Rhizosolenia are prevalent [5,6]. Since the 1990s, from the eastern Liaoning Bay to western Guangdong, more than half of the coastal sea water has been seriously polluted. Compared with category 2 in the Sea Water Quality Standard (GB3097-1997, GB means national standard), the inorganic nitrogen of coastal area of Yellow Sea and Bohai Sea has exceeded $46 \%$ and $45 \%$ and the heavy metals exceed $19 \%$ and $42 \%$, respectively. The chemical oxygen demand of inshore Bohai Sea water exceeded 13\%, which can cause serious damage to the marine algal biodiversity [8].

\subsection{Algal Biodiversity in China Freshwater Bodies}

There are diverse and abundant freshwater algae in China. The species of Diatomeae and Chlorophyta are more abundant than those of other phyla. The species number of freshwater algae in China accounts for $45 \%$ of the whole World number. Nearly a century of investigation has shown that all the categories of freshwater algae occur in China and the species are abundant. It has been shown that the total number of freshwater algae is about 25,000 and 9000 species have been recorded from China [5]. However, there are still many areas have not been surveyed and some areas have been surveyed, but not comprehensively.

Meanwhile, although the algal resources of China are plentiful, they are severely threatened. Nowadays more than 850 out of 1200 rivers in China have been contaminated, leading to the extinction of many species. The tasks of restoration and reconstruction of aquatic habitat are urgent [8] and the attention of conservationists to biodiversity only focuses on large animals and higher plants, but the small algae are generally neglected [5]. Among the largest groups of microalgae, Cyanophyceae, 
Chlorophyceae, Bacillariophyceae and Chrysophyceae are the most frequently cited as possessing the most desirable features for efficient and economical combination of $\mathrm{CO}_{2}$ fixation, wastewater treatment and lipids for biofuel production [9].

\subsection{Algal Production in Open Ponds}

Compared with other cultivation methods, algal production in open ponds with low-cost construction and low operating costs has obvious advantages. Also, microalgal production in open ponds contributes to carbon emission reduction, compared with other cultivation modes. Almost all the commercial-scale microalgal products are made using this method. Common species of algae used in open ponds are shown in Table 2. To find algal species with rapid accumulation of biomass and at the same time containing large quantity of algae biofuel is a problem. Fast growing species always tend to produce less biofuel, according to Professor Zhang Yuanhui (University of Illinois at Urbana-Champaign), who used fast-growing algae to produce biocrude oil through thermochemical conversion.

Table 2. Biomass production of several microalgae spp. in open ponds.

\begin{tabular}{|c|c|c|c|}
\hline Species & Yield g/(L·d) & Yield $g /\left(m^{2} \cdot d\right)$ & References \\
\hline Spirulina maxima & 0.21 & 25 & {$[10,11]$} \\
\hline Chlorella vulgaris & 0.18 & & [10] \\
\hline Scenedesmus obliquus & 0.09 & & {$[10]$} \\
\hline Dunaliella tertiolecta & 0.12 & & {$[10]$} \\
\hline Nannochloropsis sp. & $0.09-0.31$ & & {$[10]$} \\
\hline Neochloris oleabundans & 0.09 & & {$[10]$} \\
\hline Haematococcus pluvialis & & $15.1-70.4$ & {$[12]$} \\
\hline Spirulina platensis & $0.06-0.18$ & $15-51$ & {$[11,13]$} \\
\hline Scenedesmus sp. & $0.03-0.13$ & $2.43-13.5$ & [14] \\
\hline Chlorella sp. & $0.02-2.9$ & $1.61-25.0$ & {$[14,15]$} \\
\hline Pleurochrysis carterae & $0.02-0.22$ & $3.20-35.2$ & [16] \\
\hline Dunaliella salina & $0.22-0.34$ & $1.6-37.7$ & [17] \\
\hline Spirulina sp. & $0.006-0.07$ & $2-17$ & [18-20] \\
\hline Anabaena sp. & $0.031-0.078$ & $4.9-23.5$ & {$[14,21]$} \\
\hline Phaeodactylum tricornutum & $0.0028-0.16$ & $2.4-11.3$ & {$[22,23]$} \\
\hline Nannochloris sp. & $0.29-0.32$ & & [23] \\
\hline
\end{tabular}

\subsection{Algal Culture Collections in China}

For screening and selecting excellent algal strains and some species in danger of extinction from natural environments, algal culture collections are necessary to preserve the biodiversity of natural habitats, patent microalgae that adapt to practical conditions better and grow well, to protect genetic material and provide basic research resources as well. At present, several algal collection centers have been set up in China, such as the Freshwater Algae Culture Collection (FACHB) in Wuhan, which has more than 100 genera, 800 strains of freshwater algae, 3000 branches and a small amount of salt and seawater species. The Marine Biological Culture Collection Centre (MBCCC) in Qingdao has collected more than 600 strains of marine algal resources, close to them being $70 \%$ oil-producing algae species. In China there are other culture collections at some universities like Jinan University in Guangzhou, 
Ningbo University in Zhejiang and Ocean University of China in Qingdao. The number of cultured algal species is much less than those of described algal species and suitable media need further investigation. Microalgae isolated from wastewater treatment plant sites or real bodies of water can adapt to practical conditions well and grow better.

\section{Resource Availability in China}

\section{1. $\mathrm{CO}_{2}$ Sources}

Generally speaking, the atmosphere contains only $0.03-0.06 \% \mathrm{CO}_{2}$. This is far from adequate to cultivate microalgae. The utilization of high concentration $\mathrm{CO}_{2}$ from industrial flue gas for large-scale algal cultivation is a very promising method, not only for $\mathrm{CO}_{2}$ emission mitigation but also for the production of biofuels and high value products. The $\mathrm{CO}_{2}$ industrial point sources are mainly from power plants, cement and steel works, which account for about $91.7 \%$ of the total emissions. Power plants' relative $\mathrm{CO}_{2}$ emissions made up $63 \%$ of the main industrial sources in 2004 . The highest concentration of $\mathrm{CO}_{2}$ was from the ammonia industry, which contained $100 \% \mathrm{CO}_{2}$ and cement production which contained $20 \% \mathrm{CO}_{2}$ (Table 3) [24].

Table 3. Large scale and high concentration $\mathrm{CO}_{2}$ sources in China.

\begin{tabular}{|l|c|c|}
\hline $\mathbf{C O}_{\mathbf{2}}$ Sources & $\mathbf{C O}_{\mathbf{2}}$ Relative Emissions (\%) & Concentration (\%) \\
\hline Power plants & 63 & 15 \\
Cement production & 19 & 20 \\
Ethylene & 1 & 12 \\
Steel works & 10 & 15 \\
Refineries & 3 & 8 \\
Ammonia & 4 & 100 \\
\hline
\end{tabular}

The geographical distribution of $\mathrm{CO}_{2}$ emissions of the main sources (power plants, cement production, steelworks, refineries, ethylene and ammonia plants) with large-scale and high concentration sources is presented in Figure 1 [24]. The distribution of $\mathrm{CO}_{2}$ emission industrial point sources were concentrated located in Bohai Sea Bay, Yangtze River Delta, Pearl River Delta such as Shandong, Jiangsu, Hebei and Guangdong provinces.

Usually the production of per ton of algal dry biomass will assimilate about 1.83 tons of $\mathrm{CO}_{2}$. Microalgae can use about $9 \%$ of the solar energy to produce 280 tons of dry biomass per ha $\mathrm{y}^{-1}$ while sequestering roughly 513 tons of $\mathrm{CO}_{2}$ [25]. The requirements for $\mathrm{CO}_{2}$ supply to enhance algal production and matching of $\mathrm{CO}_{2}$ source availability with algal cultivation facilities is not just a simple question. Optimal algal growth could provide excellent opportunity for the utilization of GHG emissions. Some algae can tolerate high $\mathrm{CO}_{2}$ concentrations and the temperature of flue gas containing trace constituents such as $\mathrm{SO}_{\mathrm{x}}$ and $\mathrm{NO}_{\mathrm{x}}$. Common species of algae for $\mathrm{CO}_{2}$ utilization are shown in Table 4. 
Figure 1. The geographical distribution of $\mathrm{CO}_{2}$ industrial point sources.

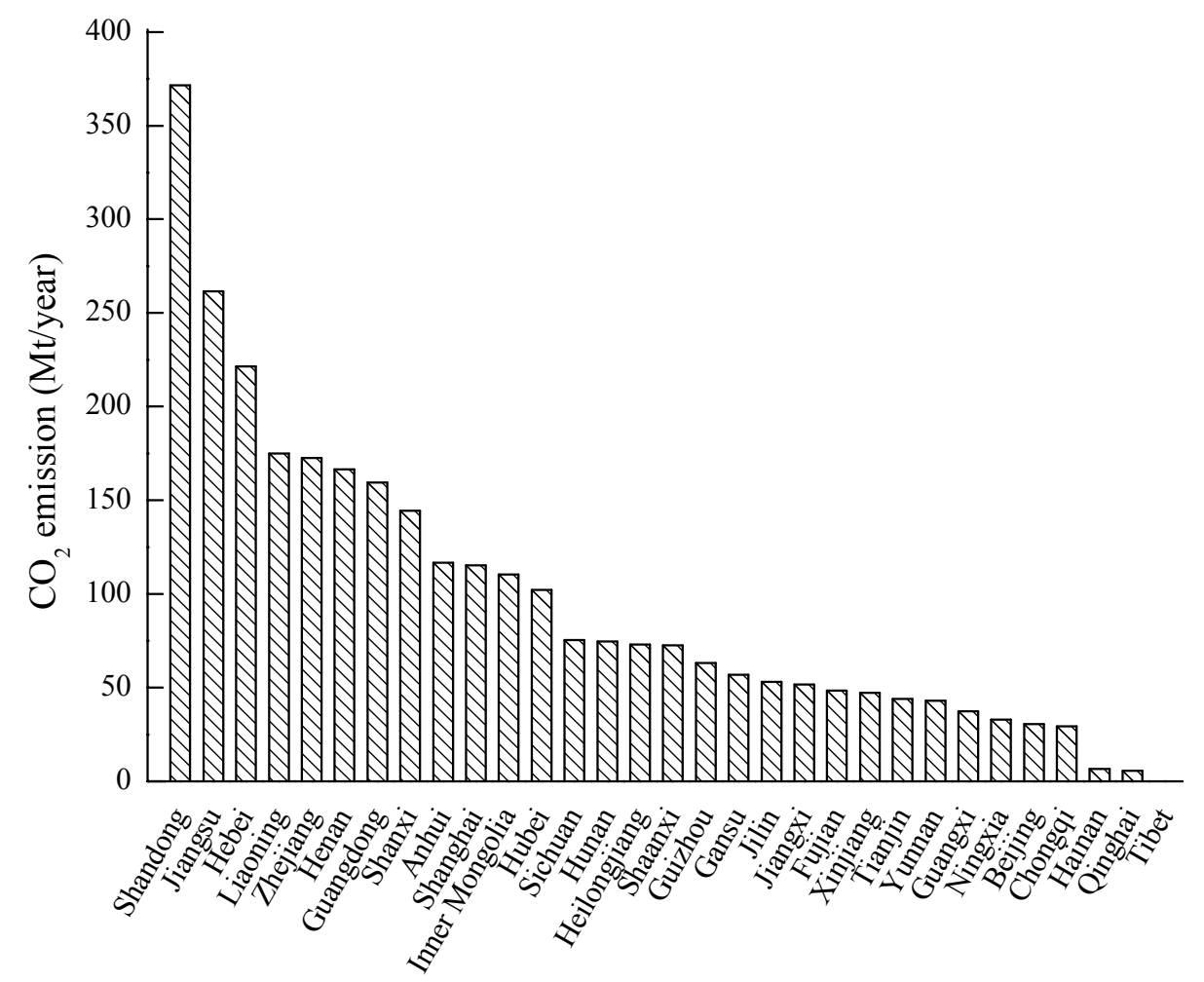

Table 4. Biomass productivity, $\mathrm{CO}_{2}$ fixation and specific growth rates for different microalgae.

\begin{tabular}{|c|c|c|c|c|c|}
\hline Species & $\mathrm{CO}_{2}(\%)$ & $\begin{array}{c}\text { Biomass } \\
\text { Productivity } \\
\left(\mathrm{mg} \mathrm{L}^{-1} \mathrm{~d}^{-1}\right)\end{array}$ & $\begin{array}{c}\mathrm{CO}_{2} \text { Fixation } \\
\text { Rates } \\
\left(\mathrm{mg} \mathrm{L}^{-1} \mathrm{~d}^{-1}\right)\end{array}$ & $\mu\left(d^{-1}\right)$ & References \\
\hline Botryococcus braunii & $5-10$ or flue gas & 26.55 & 496.98 & 0.24 & [26-28] \\
\hline Scenedesmus sp. & 10 or flue gas & 217.50 & & & [26] \\
\hline Chlorella vulgaris & $5-10$ & $104.76-310$ & 251.64 & 0.29 & {$[26,28]$} \\
\hline Spirulina platensis & 5 & 730 & 318.61 & 0.22 & [28] \\
\hline Dunaliella tertiolecta & 5 & 420 & 272.4 & 0.21 & [28] \\
\hline Chlorella sp. & $0.03-15$ & $191-1484$ & $350-13,700$ & $0.58-0.66$ & {$[27,29,30]$} \\
\hline Chlorococcum littorale & $10-20$ or flue gas & $400-2500$ & $650-17,300$ & $1.8-1.9$ & {$[27,31-33]$} \\
\hline Scenedesmus obliquus & $6-12$ & $40-140$ & & $0.19-0.261$ & {$[34,35]$} \\
\hline Chlorella kessleri & 6 & $61-90$ & & & [34] \\
\hline Spirulina sp. & $6-12$ & $40-220$ & & $0.27-0.44$ & [35] \\
\hline Aphanothece microscopica & 15 & & $5612-14,495$ & & [36] \\
\hline Euglena gracilis & $5-10$ & & & 1.44 & [37] \\
\hline
\end{tabular}

\subsection{Sunlight}

Although the light intensity requirements of typical microalgae are relatively low compared with those of higher plants [9], the availability of abundant sunlight is equally important for the robust growth of photoautotrophic microalgae with both open and closed cultivation systems [38]. This is undoubtedly an important consideration since insolation is directly linked to yield. Different regions in China have vastly different day-length regimes (Figure 2). In the water, the light intensity is reduced with the depth 
and spectrum composition change. First, infrared, ultraviolet and long wavelength red light are absorbed. The short wavelength cyan and blue light are absorbed last. Algae do not need the sunlight in the same intensities (Table 5). For most algae, the appropriate range of light intensity is between $36-180 \mu \mathrm{mol} \mathrm{m}{ }^{-2} \mathrm{~s}^{-1}$, a light-dark growth is used between $12: 12$ and $16: 8 \mathrm{~h}$ but some winter strains need a longer night period. Over illumination will result in photo-oxidative stress and continuous light may lead to death in some algae. Chlorophyll absorbs red and violet light, the Cyanobacteria and red algae are rich in light-harvesting pigments, which can use sunlight that chlorophyll does not absorb in other categories. The light intensity on water surface can reach thousands of $\mu \mathrm{mol} \mathrm{m} \mathrm{m}^{-1}$ in sunny days, some algae suffer the limitations of light saturation photoinhibition [39]. China is a country with abundant solar energy resources, with solar radiation values between 6.5 to $7.5 \mathrm{kWh} \mathrm{m}^{-2} \mathrm{~d}^{-1}$. The annual average illumination time of two-thirds of the area in China is more than $2000 \mathrm{~h}$. The total illumination hours in Northwest and Qinghai-Tibetan Plateau are China's longest. China's Eastern, Southern and Northeast areas are the middle solar energy resources and Sichuan, Hubei and Hunan have lower solar energy resources.

Figure 2. Annual average percentage of sunshine in China (Source: National Meteorological Information Center).

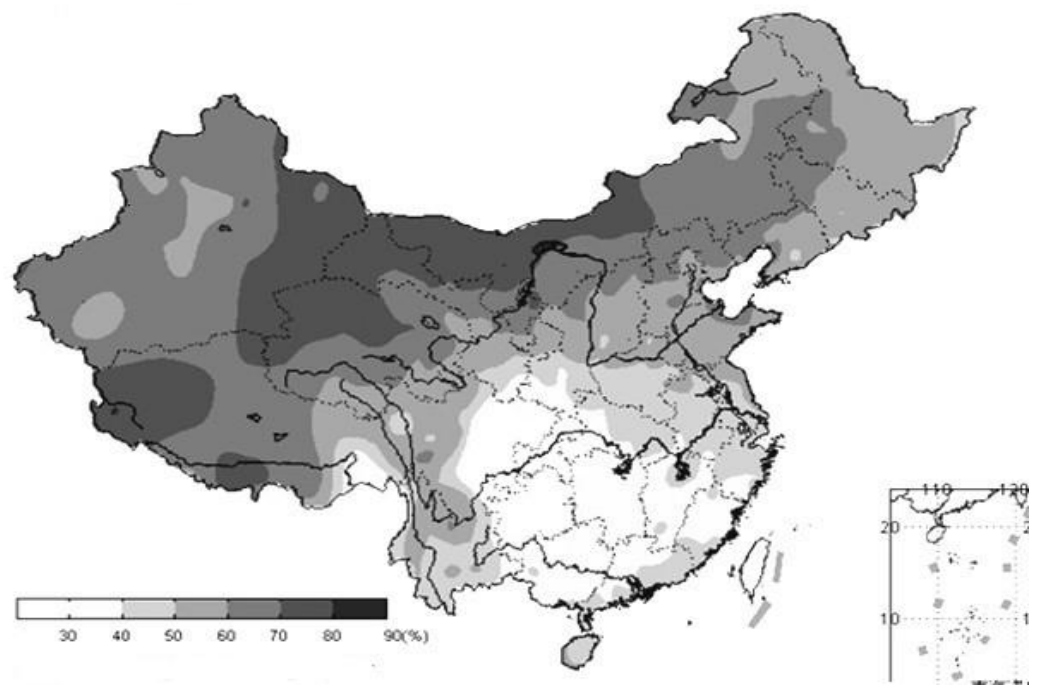

Table 5. Summary of light conditions for typical strains.

\begin{tabular}{|c|c|c|c|c|}
\hline Species & $\begin{array}{l}\text { Suitable Light } \\
\text { Intensities } \\
\left(\mu \mathrm{mol} \mathrm{m} \mathbf{m}^{-2} \mathrm{~s}^{-1}\right)\end{array}$ & $\begin{array}{c}\text { Saturation Light } \\
\text { Intensities } \\
\left(\mu \mathrm{mol} \mathrm{m} \mathbf{~ s}^{-1}\right)\end{array}$ & L/D (h) & References \\
\hline Spirulina platensis & $10 \sim 630$ & $\sim 270$ & $6: 5 \sim 8: 3,24: 0$ & [40] \\
\hline Botryococcus braunii & $400 \sim 1600$ & $\sim 800$ & $\sim 14: 10$ & [41] \\
\hline Nannochloropsis oculata & $90 \sim 126$ & - & $12: 12$ & [42] \\
\hline Haematococcus pluvialis & 70 90 & $\sim 200$ & $\sim 12: 12$ & [43] \\
\hline Dunaliella salina & $50 \sim 90$ & $\sim 220$ & $\sim 12: 12$ & [44] \\
\hline Chlorella pyrenoidosa & $120 \sim 160$ & $\sim 150$ & $\sim 10: 14$ & {$[45]$} \\
\hline Nitzschia closterium & $70 \sim 160$ & - & $\sim 24: 0, \sim 12: 12$ & [46] \\
\hline
\end{tabular}




\subsection{Water}

The total water resources per capita in China are estimated at about $2245 \mathrm{~m}^{3}$, which corresponds to one third of the World's average value and thus ranks China among the most water poor countries in the World [47]. Freshwater sources which would already be restricted would likely not be available in large quantities for large scale algal cultivation. Nevertheless, China has large volumes of wastewater from urban households, industry and animal husbandry.

In 2008, the amount of discharge of industrial and urban household wastewater nationwide was calculated to be about 57.2 billion tons, with that of the latter reaching 33.0 billion tons [48]. From the geographical distribution of the amount of wastewater emissions in 2008 (Figure 3), we find the main wastewater distribution areas were in the southeast coast, eastern and southern China, especially, in Guangdong, Jiangsu, Shandong, Zhejiang and Guangxi. The largest amount of industrial wastewater discharge was located in Jiangsu and the largest urban household and total wastewater was presented in Guangdong. From Figure 4, we also knew that the statistics of swine wastewater emissions were steady at about 4.1-4.5 million $\mathrm{m}^{3}$ in recent years [48]. Algae can utilize those wastewaters (Table 6), which usually contains relatively high inorganic nutrient levels and there has a great potential for the removal of nitrogen and phosphorus for algae growing and at the same time accumulating lipids in algal cells.

Figure 3. The distribution of wastewater emissions in 2008.

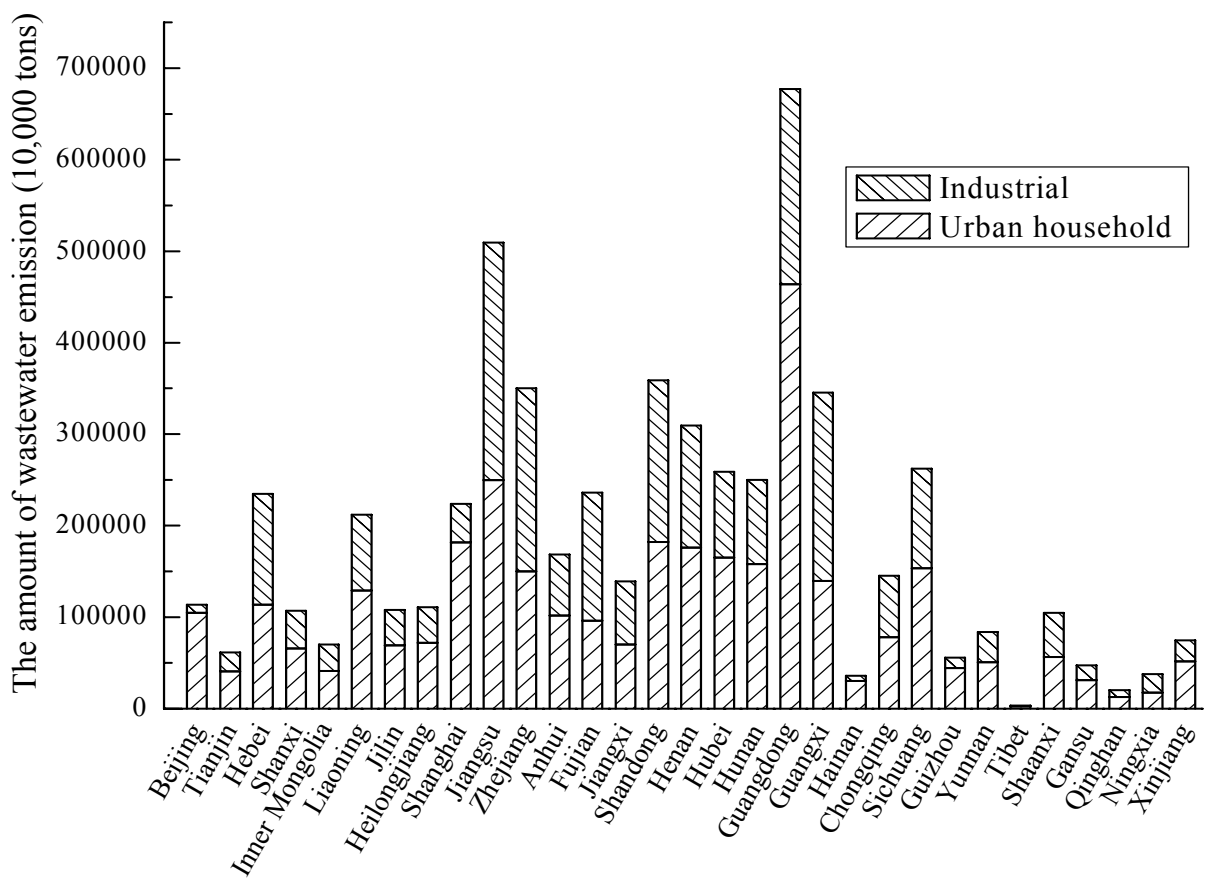


Figure 4. Piggery wastewater emissions in China.

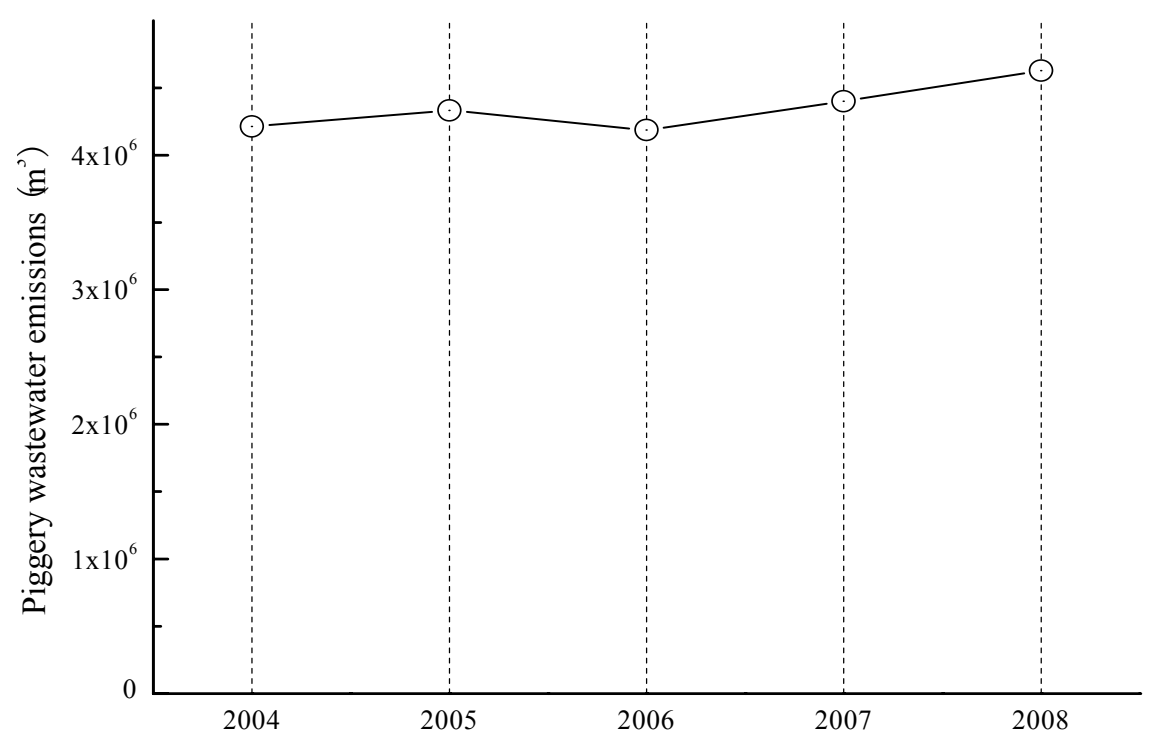

Table 6. Typical strains cultivated in wastewater.

\begin{tabular}{|l|l|l|l|}
\hline \multicolumn{1}{|c|}{ Species } & \multicolumn{1}{|c|}{ Type of Sewage } & \multicolumn{1}{|c|}{ Process } & References \\
\hline Scenedesmus sp. & $\begin{array}{l}\text { Urban wastewater from } \\
\text { secondary treatment or } \\
\text { Synthetic }\end{array}$ & Batch; Semicontinuous & {$[49,50]$} \\
\hline Spirulina (Arthrospira) sp. & $\begin{array}{l}\text { Pig wastewater } \\
\text { anaerobic effluents }\end{array}$ & Outdoor raceways & {$[51]$} \\
\hline Chlamydomonas reinhardtii & $\begin{array}{l}\text { Different stages from } \\
\text { Metropolitan } \\
\text { Wastewater Treatment } \\
\text { Plant }\end{array}$ & Batch; Biocoil photobioreactor & {$[52]$} \\
\hline Chlorella sp. & Dairy manure & Attached & \\
\hline Scenedesmus obliquus & $\begin{array}{l}\text { Olive-oil mill; urban } \\
\text { wastewater }\end{array}$ & $\begin{array}{l}\text { Photobioreactor; Semicontinuous; } \\
\text { Batch }\end{array}$ & {$[54-56]$} \\
\hline $\begin{array}{l}\text { Chlamydomonas globosa; } \\
\text { Chlorella minutissima } \text { and } \\
\text { Scenedesmus bijuga }\end{array}$ & $\begin{array}{l}\text { Untreated carpet } \\
\text { industry }\end{array}$ & $\begin{array}{l}\text { Raceway ponds; Vertical tank } \\
\text { reactors and polybags }\end{array}$ & {$[57]$} \\
\hline Chlorella vulgaris & $\begin{array}{l}\text { Municipal; Synthetic; } \\
\text { Steel-making facility; } \\
\text { Distillery }\end{array}$ & $\begin{array}{l}\text { Immobilized; Photobioreactor; } \\
\text { Batch; Microalgae pond }\end{array}$ & {$[56,58-62]$} \\
\hline Chlorella sorokinia & Municipal & Immobilized & {$[63]$} \\
\hline $\begin{array}{l}\text { Phaeodactylum tricornutum, } \\
\text { Oscillatoria } \text { sp. }\end{array}$ & $\begin{array}{l}\text { Primary sewage and } \\
\text { seawater }\end{array}$ & Corrugated raceways & {$[63]$} \\
\hline Scenedesmus rubescens & Synthetic; municipal & Immobilization & {$[64]$} \\
\hline Senedesmus dimorphu & Analogue wastewater & Bio-coil reactor conical flask & {$[65]$} \\
\hline Monoraphidium & $\begin{array}{l}\text { Tertiary treatment of } \\
\text { urban wastewater }\end{array}$ & & {$[66]$} \\
\hline Aphanothece microscopica & Refinery industry & Photobioreactor & {$[67]$} \\
\hline Botryococcus braunii & Livestock wastewater & Batch & {$[68]$} \\
\hline
\end{tabular}




\subsection{Land}

Land is hardly a limitation for algae cultivation. Algae cultivation uses land roughly 3.3 times more efficiently than corn, 4.3 times more efficiently than switchgrass and 5 times more efficiently than canola [69] and microalgae also do not need to compete with land used for food crops. They can encroach on pasture, grass land and even relatively sterile desert (Figure 5). The Gobi desert covering Southern Mongolia and Northern China is the highest solar radiation area, and many salt lakes are distributed there which are natural sources for nutrition of algae growth. Over the past decade, three microalgae (mainly Chlorella sp.) production plants have been built in Qingyang and Wuwei of Gansu Province, Erdos of Inner Mongolia Autonomous Region [4]. Those area should also be generally accessible and already serviced by roads and power.

Figure 5. The desert and Gobi areas of China [48].

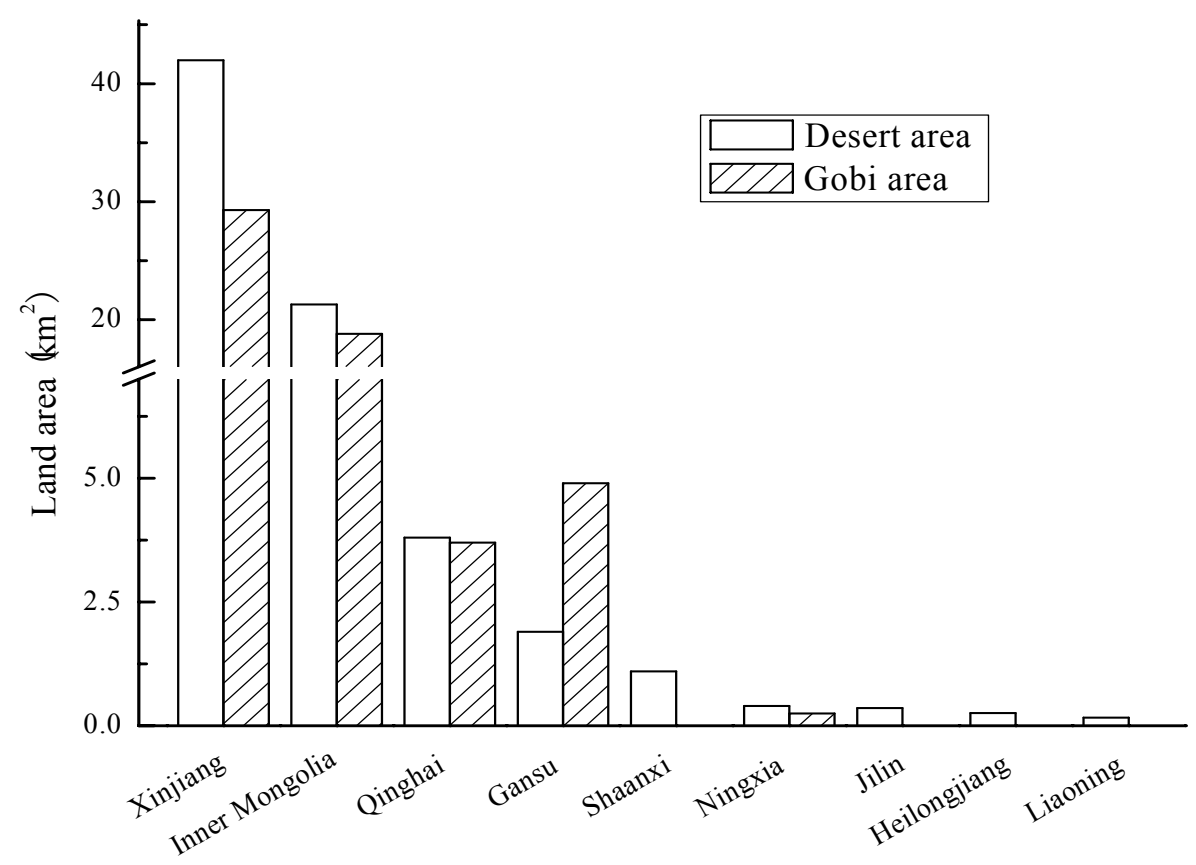

\section{Microalgae R\&D Efforts in China}

In the 1950s, research on microalgae, i.e., Chlorella use cultivation was started in the Institute of Hydrobiology under the auspices of the Chinese Academy of Sciences (CAS). With the passage of time in the 1980s, large scale cultivation of Spirulina and Dunaliella was listed in the national research program (the 7th Five-Year Plan). In the last decade the microalgae industry in China had been developing rapidly and has made remarkable achievements. In 1984, the Salt Research Institute, affiliated with the former China Light Industry Association, began to study Dunaliella cultivation for the extraction of natural carotene. In 1989, the first Spirulina production pilot factory was established in Chenghai Lake, Yunnan. In 1999, Guangdong Jinqiu Green Algae Co., Ltd. built a 10,000 km² Chlorella production base. In 2001, the production of algae powder was more than 10 tons. Those microalgae were all cultivated for various nutritional products [70]. According to International Energy Agency (IEA), the 
total world production of dry algal biomass is estimated about 10,000 tons per year, among which half of the yield is produced in mainland China.

China has started to promote its algae based energy as early as 2005. The fundamental research on energy microalgae in China has a strong scientific and technological base. Varies universities and research institutes are undertaking large numbers of national and provincial level research projects on microalgae classification, breeding and preservation technology. For example, microalgal hydrogen production at the Dalian Institute of Chemical Physics (CAS), microalgal oil production at Ocean University of China, Tsinghua University and other institutions have much more research basis. ENN Group Co., Ltd. has been developing technology to use microalgae to fix $\mathrm{CO}_{2}$ and then to produce biofuel. Marine microalgae bioenergy projects have been established in Shenzhen, Guangdong in 2008. The main objective of the project was the cultivation of diatoms to fix $\mathrm{CO}_{2}$ from flue gas, later on diatoms were harvested and using for biodiesel production. In 2009, CAS and China Petrochemical Corporation (Sinopec Group) decided to develop algae biodiesel technology together. It was expected that an outdoor pilot plant will be operational in about 2015 and a 10,000 ton industrial demonstration unit would be set up in the near future. However, lots of algae breeding work is still in the research and development stage and strains are not qualified for industrialization at present. The mass culturing technology of algae is still immature and lack a relevant criteria or evaluation system in China.

\section{Conclusions}

China has a vast sea area and a great number of rivers and lakes, resulting in abundant algal resources. For algal large-scale production, we should select construction in the vicinity of high $\mathrm{CO}_{2}$ emission enterprises such as power plants, cement and steel works. Wastewaters from urban households, industry and animal husbandry are needed to collect and treat for algal utilization. Free sunlight and robust strain screening are important as well. In all, technology development and coordinated management for cost reduction are needed to utilize those waste and free resources. Algal bioenergy is still in its infancy and further investigation is required.

\section{Acknowledgments}

This study was supported by the National Program on Key Basic Research Project of China (973 Program) (2011CB200905), the 11th and 12th Five Year Support Plan of the Ministry of Science and Technology, P. R. China (2008BADC4B00, 2011BAD14B03), the Guangdong Chinese Academy of Sciences Comprehensive Strategic Cooperation Project (2010A090100010) and the Innovation Fund for Graduate Student of China Agricultural University (15050207).

\section{References}

1. The National Renewable Energy Laboratory (NREL). Jet Fuel from Microalgal Lipids; NREL: Golden, CO, USA, July 2006. Available online: http://www.nrel.gov/docs/fy06osti/40352.pdf (accessed on 16 August 2011).

2. Demirbas, A.; Fatih Demirbas, M. Algae Energy: Algae as a New Source of Biodiesel; Springer-Verlag: London, UK, 2010. 
3. Sheehan, J.; Dunahay, T.; Benemann, J.; Roessler, P. A Look Back at the U.S. Department of Energy's Aquatic Species Program: Biodiesel from Algae; NREL Report No. TP-580-24190; NREL: Golden, CO, USA, July 1998.

4. Tian,Y. Leaving the Sunlight-Thought and Practice on the Microalgae Photoreactor; Popular Science Press: Beijing, China, 2008.

5. Zhang, W. China's Biodiversity: A Country Study; China Environmental Science Press: Beijing, China, 1998.

6. Liu, R. Checklist of Marine Biota of China Seas; Science Press: Beijing, China, 2008.

7. Nelson, D.M.; Treguer, P. Production and dissolution of biogenic silica in the ocean: Revisedglobal estimates, comparison with regional data and relationship to biogenic sedimentation. Global Biogeochem. Cycles 1995, 9, 359-372.

8. Liu, X. The Report of Conservation of Chinese Bio-diversity Resources; Science Press: Beijing, China, 2004.

9. Kumar, A.; Ergas, S.; Yuan, X. Enhanced $\mathrm{CO}_{2}$ fixation and biofuel production via microalgae: Recent developments and future directions. Trends Biotechnol. 2010, 28, 371-380.

10. Gouveia, L.; Oliveira, A.C. Microalgae as a raw material for biofuels production. J. Ind. Microbiol. Biotechnol. 2009, 36, 69-274.

11. Lee, Y. Microalgal mass culture systems and methods: Their limitation and potential. J. Appl. Phycol. 2001, 13, 307-315.

12. Huntley, M.E.; Redalje, D.G. $\mathrm{CO}_{2}$ mitigation and renewable oil from photosynthetic microbes: A new appraisal. Mitig. Adapt. Strateg. Global Change 2007, 12, 573-608.

13. Pushparaj, B.; Pelosi, M.R.; Tredici, E. An integrated culture system for outdoor production of microalgae and cyanobacteria. J. Appl. Phycol. 1997, 9, 113-119.

14. Kanazawa, Z.; Fujita, C.; Yuhara, T.; Sasa, T. Mass culture of unicellular algae using the open pond circulation method. J. Gen. Appl. Microbiol. 1958, 4, 135-139.

15. Doucha, J.; Straka, F.; Karel, L. Utilization of flue gas for cultivation of microalgae (Chlorella sp.) in an outdoor open thin layer photobioreactor. J. Appl. Phycol. 2005, 17, 403-412.

16. Moheimani, N.R.; Borowitzka, M.A. The long-term culture of the coccolithophore Pleurochrysis carterae (Haptophyta) in outdoor raceway ponds. J. Appl. Phycol. 2006, 18, 703-712.

17. Garcia, G.M.; Moreno, J.; Canavate, J.P.; Anguis, V.; Prieto, A. Conditions for open-air outdoor culture of Dunaliella salina in southern Spain. J. Appl. Phycol. 2003, 15, 177-184.

18. Olguin, E.J.; Galicia, S.; do Merca, G.; Perez, T. Annual productivity of Spirulina (Arthrospira) and nutrient removal in a pig wastewater recycling process under tropical condition. J. Appl. Phycol. 2003, 15, 249-257.

19. Jimenez, C.; Cossio, B.R.; Labella, D.; Niell, F.X. The feasibility of industrial production of Spirulina (Arthrospira) in southern Spain. Aquaculture 2003, 217, 179-190.

20. Richmond, A. Spirulina, Micro-Algal Biotechnology; Cambridge University Press: Cambridge, UK, 1988; pp. 85-121.

21. Moreno, J.; Vargas, A.; Rodriguez, H. Rivas, J.; Guerrero, M.G. Outdoor cultivation of a nitrogen-fixing marine cyanobacterium, Anabaena sp. ATCC 33047. Biomol. Eng. 2003, 20, 191-197. 
22. Laws, E.A.; Terry, K.L.; Wickman, J.; Chalup, M. A simple algal production system designed to utilise the flashing light effect. Biotechnol. Bioeng. 1983, 25, 2319-2335.

23. Negoro, M.; Shioji, N.; Miyamoto, K.; Miura, Y. Growth of microalgae in high $\mathrm{CO}_{2}$ gas and effects of $\mathrm{SO}_{\mathrm{x}}$ and $\mathrm{NO}_{\mathrm{x}}$. Appl. Biochem. Biotechnol. 1991, 28/29, 877-886.

24. Bai, B.; Li, X.; Liu, Y.; Zhang, Y. Preliminary study on $\mathrm{CO}_{2}$ industrial point sources and their distribution in China. Chin. J. Rock Mech. Eng. 2006, 25, 2918-2923.

25. Bilanovic, D.; Andargatchew, A.; Kroeger, T.; Shelef, G. Freshwater and marine microalgae sequestering of $\mathrm{CO}_{2}$ at different $\mathrm{C}$ and $\mathrm{N}$ concentrations-Response surface methodology analysis. Energy Convers. Manag. 2009, 50, 262-267.

26. Yoo, C.; Jun, S.; Lee, J.; Ahn, C.; Oh, H. Selection of microalgae for lipid production under high levels carbon dioxide. Bioresour. Technol. 2010, 101, 71-74.

27. Murakami, M.; Ikenouchi, M. The biological $\mathrm{CO}_{2}$ fixation and utilization project by rite 2. Energy Convers. Manag. 1997, 38, S493-S497.

28. Sydney, E.B.; Sturm, W.; de Carvalho, J.C. Potential carbon dioxide fixation by industrially important microalgae. Bioresour. Technol. 2010, 101, 5892-5896.

29. Fulke, A.B.; Mudliar, S.N.; Yadav, R.; Shekh, A.; Srinivasan, N.; Rishiram, R.; Krishnamurthi, K.; Devi, S.S.; Chakrabarti, T. Bio-mitigation of $\mathrm{CO}_{2}$, calcite formation and simultaneous biodiesel precursors production using Chlorella sp. Bioresour. Technol. 2010, 101, 8473-8476.

30. Ryu, H.J.; Oh Kyeong, K.; Kim, Y.S. Optimization of the influential factors for the improvement of $\mathrm{CO}_{2}$ utilization efficiency and $\mathrm{CO}_{2}$ mass transfer rate. J. Ind. Eng. Chem. 2009, 15, 471-475.

31. Kurano, N.; Ikemoto, H.; Miyashita, H.; Hasegawa, T.; Hata, H.; Miyachi, S. Fixation and utilization of carbon dioxide by microalgal photosynthesis. Energy Convers. Manag. 1995, 36, 689-692.

32. Kurano, N.; Ikemoto, H.; Miyashita, H. Fixation and utilization of carbon dioxide by microalgal photosynthesis. Energy Convers. Manag. 1995, 36, 689-692.

33. Kurano, N.; Sasaki, T.; Miyachi, S. Advances in chemical conversions for mitigating carbon dioxide. Stud. Surf. Sci. Catal. 1998, 114, 55-63.

34. Morais, M.G.; Costa, J.A.V. Isolation and selection ofmicroalgae fromcoal fired thermoelectric power plant for biofixation of carbon dioxide. Energy Convers. Manag. 2007, 48, 2169-2173.

35. De Morais, M.G.; Costa, J.A. Biofixation of carbon dioxide by Spirulina sp. and Scenedesmus obliquus cultivated in a three-stage serial tubular photobioreactor. J. Biotechnol. 2007, 129, 439-445.

36. Jacob-Lopesa, E.; Revahb, S.; Hernández, S. Development of operational strategies to remove carbon dioxide in photobioreactors. Chem. Eng. J. 2009, 135, 120-126.

37. Chae, S.R.; Hwang, E.J.; Shin, H.S. Single cell protein production of Euglena gracilis and carbon dioxide fixation in an innovative photo-bioreactor. Bioresour. Technol. 2006, 97, 322-329.

38. National Algal Biofuels Technology Roadmap; U.S. Department of Energy: Washington, DC, USA, 2010.

39. Chen, F. Microalgae Biotechnology; China Light Industry Press: Beijing, China, 1999.

40. Wang, B.; Mao, H.; Jiao, Z.; Zheng, Y. The analysis of cultivating Spirulina on agro-meteorological conditions in chenghai lake. Yunnan Geogr. Environ. Res. 2009, 6, 25-28. 
41. Yin, D.; Geng, Y.; Mei, H. The effects of several environmental factors on the photosynthesis of Botryococcus braunii. J. Wuhan Bot. Res. 2008, 26, 64-69.

42. Jiang, X. Effects of temperatures, light intensities and nitrogen concentrations on the growth and fatty acid compositions of Nannochloropsis oculata. Mar. Sci. 2002, 8, 9-13.

43. Lu, K.; Jiang, X.; Zhai, X. Effects of illumination on growth of Haematococcus pluvialis. Hebei Fish. 2002, 6, 6-8.

44. Lin, G. Study on the conditions of high density cultivation of Dunaliella salina. Shandong Fish. 2007, 9, 41-44.

45. Wen, G.; Liang, W.; Li, Z. Studies on the ecological factors of four microalgae populations in mixed-culture. Prog. Fish. Sci. 2009, 30, 142-148.

46. Shi, J.; Pan, K. Effects of different light intensities on growth and biochemical composition of Nitzschia closterium f. minutissima and Isochrysis galbana Parke 8701. J. Fish. Sci. China 2004, 11, 121-128.

47. Li, W.; Wang, R. Water Resources Ecosystem Management in China-Challenges and Opportunities. In Proceedings of the Ecosystem Service and Sustainable Watershed Management in North China International Conference, Beijing, China, 23-25 August 2000.

48. National Bureau of Statistics of China. China Statistical Yearbook; China Statistics Press: Beijing, China, 2004-2009.

49. Li, X.; Hu, H.; Yang, J. Lipid accumulation and nutrient removal properties of a newly isolated freshwater microalga, Scenedesmus sp. LX1, growing in secondary effluent. New Biotechnol. 2010, 27, 59-63.

50. Voltolina, D.; Gómez-villa, H.; Correa, G. Biomass production and nutrient removal in semicontinuous cultures of Scenedesmus sp. (chlorophyceae) in artificial wastewater, under a simulated day-night cycle. Vie Milieu 2004, 54, 21-25.

51. Olguín, E.J. Annual productivity of Spirulina (Arthrospira) and nutrient removal in a pig wastewater recycling process under tropical conditions. J. Appl. Phycol. 2003, 15, 249-257.

52. Kong, Q.; Li, L. Culture of Microalgae Chlamydomonas reinhardtii in wastewater for biomass feedstock production. Appl. Biochem. Biotechnol. 2010, 160, 9-18.

53. Michael, B.; Wen, Z. Development of an attached microalgal growth system for biofuel production. Appl. Microbiol. Biotechnol. 2010, 5, 525-534.

54. Hodaifa, G. Daily doses of light in relation to the growth of Scenedesmus obliquus in diluted three-phase olivemill wastewater. J. Chem.Technol. Biotechnol. 2009, 84, 1550-1558.

55. Voltolina, D. Nitrogen removal and recycling by Scenedesmus obliquus in semicontinuous cultures using artificial wastewater and a simulated light and temperature cycle. Bioresour. Technol. 2005, 96, 359-362.

56. Martinez, M.E.; Sancheze, S.; Jimenez, J.M. Nitrogen and phosphorus removal from urban wastewater by the microalga Scenedesmus obliquus. Bioresour. Technol. 2000, 73, 263-272.

57. Chinnasamy, S.; Bhatnagar, A., Claxton, R. Biomass and bioenergy production potential of microalgae consortium in open and closed bioreactors using untreated carpet industry effluent as growth medium. Bioresour. Technol. 2010, 101, 6751-6760. 
58. De-Bashana, L.E.; Moreno, M.; Hernandez, J.P. Removal of ammonium and phosphorus ions from synthetic wastewater by the microalgae Chlorella vulgaris coimmobilized in alginate beads with the microalgae growth-promoting bacterium Azospirillum brasilense. Water Res. 2002, 36, 2941-2948.

59. Shi, J. Removal of nitrogen and phosphorus from wastewater using microalgae immobilized on twin layers: An experimental study. J. Appl. Phycol. 2007, 19, 417-423.

60. Kapdan, I. K.; Aslan, S. Application of the Stover-Kincannon kinetic model to nitrogen removal by Chlorella vulgaris in a continuously operated immobilized photobioreactor system. J. Chem. Technol. Biotechnol. 2008, 83, 998-1005.

61. Yun, Y.; Sun, B. Carbon dioxide fixation by algal cultivation using wastewater nutrients. J. Chem. Technol. Biotechnol. 1997, 69, 451-455.

62. Travieso, L.; Benítez, F.; Sánchez, E. Performance of a laboratory-scale microalgae pond for secondary treatment of distillerywastewaters. Chem. Biochem. Eng. 2008, 22, 467-473.

63. De-Bashan, L.E.; Hernandez, J.-P.; Morey, T. Microalgae growth-promoting bacteria as "helpers" for microalgae: A novel approach for removing ammonium and phosphorus from municipal wastewater. Water Res. 2004, 38, 466-474.

64. Rupert, J.; Paul, J.; Valerie Smith, J. Wastewater nutrient removal by marine microalgae grown on a corrugated raceway. Water Res. 1997, 31, 1701-1707.

65. Liu, Y.; Ruan, R.; Kong, Q. Mass culture of high oil content microalgae on wastewater and power plant flue gases. Chin. J. Bioprocess Eng. 2008, 3, 29-33.

66. Larsdotter, K.; Jansen, J. Phosphorus removal from wastewater by microalgae in Sweden a year round perspective. Environ. Technol. 2010, 31, 117-123.

67. Jacob-Lopes, E. Biotransformations of carbon dioxide in photobioreactors. Energy Convers. Manag. 2010, 51, 894-900.

68. Shen, Y.; Yuan, W.; Pei, Z.; Mao, E. Culture of microalga Botryococcus in livestock wastewater. Trans. ASABE 2008, 51, 1395-1400.

69. Clarens, A.F.; Resurreccion, E.P.; White, M.A; Colosi, L.M. Environmental life cycle comparison of algae to other bioenergy feedstocks. Environ. Sci. Technol. 2010, 44, 1813-1819.

70. Ling, F. The trend of microalgae industry in China. Ecol. Econ. 2004, 2, 58-61.

(C) 2011 by the authors; licensee MDPI, Basel, Switzerland. This article is an open access article distributed under the terms and conditions of the Creative Commons Attribution license (http://creativecommons.org/licenses/by/3.0/). 